\title{
KELUASAN MAKNA KATA-KATA BAHASA INDONESIA DAN KATA BAHASA MELAYU PATTANI YANG DIGUNAKAN OLEH MAHASISWA THAILAND DI UNIVERSITAS MUHAMMADIYAH SURAKARTA
}

\author{
(THE BREADTH OF MEANING OF INDONESIAN WORDS LANGUAGE AND \\ MALAY PATTANI WORDS LANGUAGE USED BY THAILAND STUDENTS IN \\ UNIVERSITY OF MUHAMMADIYAH SURAKARTA)
}

\begin{abstract}
Abdulkarim Duerawee
Jabatan Bahasa Melayu Universiti Fatoni

Pos-el : takwa0557@gmail.com

Diterima: 9 April 2018; Direvisi: 9 Mei 2018; Disetujui: 21 Mei 2018

Abstrak

Penelitian ini bertujuan menentukan kelusan makna kata dalam bahasa Indonesia dan dalam bahasa Melayu Pattani yang diujarkan oleh mahasiswa Thailand di Universitas Muhammadiyah Surakarta. Metode penelitian ini adalah deskriptif kualitatif. Sumber data penelitian adalah tuturan-tuturan dalam bentuk kalimat atau kata-kata yang diujarkan oleh Mahasiswa Thailand di Universitas Muhammadiyah Surakarta. Teknik pengumpulan data penelitian ini adalah teknik simak bebas libat cakap, rekam, dan wawancara, terakhir menganalisisnya. Teknik analisis data menggunakan metode padan dan metode analisis kontrastif. Hasil penelitian ini ada dua, pertama, kata-kata yang maknaya lebih luas dalam bahasa Indonesia. Kata tersebut mengandung beberapa komponem makna yang sama dengan bahasa Melayu Pattani, tetapi tidak semua kata terhadap bahasa Indonesia itu komponem sama maknanya, menyebabkan bahasa Melayu Pattani maknanya lebih sempit. Kedua, kata-kata yang maknanya lebih luas dalam bahasa Melayu Pattani. Kata tersebut mengandung beberapa komponem makna yang sama dengan bahasa Indonesia, tetapi tidak semua kata terhadap bahasa Melayu Pattani itu komponem sama maknanya, menyebabkan bahasa Melayu Pattani maknanya lebih luas daripada makna dalam bahasa Indonesia.
\end{abstract}

Kata kunci: keluasan makna, bahasa Indonesia, bahasa melayu, mahasiswa Thailand

\begin{abstract}
The objectives of this research are first to describe the meaning of words in Indonesian language which are different with the meaning of words in Melayu Pattani that are researched by Thailand student at Universitas of Muhammadiyah Surakarta. The second is to determine meaning of words extensively in Indonesian language with meaning of words in Melayu Pattani language that is researched by Thailand students at Universitas Muhammadiyah Surakarta. The type of research is descriptive qualitative. Data sources of this research are speech in sentences or words forms in different meaning and extensive meaning that is researched by Thailand students at Universitas Muhammadiyah Surakarta. Technique of collecting data uses free speech method, recording, and interview, and analysis. Data analysis uses comparison and contrastive method. The results of this research are (1) words in Indonesian language found that include different meaning such as the similar words, writing and even the same of speech with different meaning. (2), words that have more extensive meaning than words in Indonesian language. That words include some meaning that are similar to words in Melayu Pattani language. But not all words have the same meaning because Melayu Pattani language has narrow meaning. (3) The words that have more extensive meaning in Melayu Pattani than the meaning in Indonesian language.
\end{abstract}

Keywords: breadth meaning words, Indonesian language, Melayu language, Thailand student 


\section{Pendahuluan}

Bahasa pada hakikatnya adalah sistem simbol. Rangkaian bunyi yang dikeluarkan manusia merujukan pada fakta atau objek di luarnya (Wardhaugh, 1972: 7), seperti rangkaian bunyi $/ k / u / r / s / i /$ yang merujuk kepada benda yang berkaki empat yang biasa terbuat dari kayu, berguna untuk duduk. Setiap bangsa mempunyai bahasa dan setiap suku bangsa atau etnik mempunyai bahasa tertentu. Unsur bahasa Indonesia yang mengandung persamaan sekaligus perbedaan dengan unsur bahasa Melayu Pattani adalah makna. Makna dalam bahasa Indonesia dengan makna dalam bahasa Melayu Pattani terdapat perbedaan, kemiripan, dan persamaannya.

Salah satu fenomena yang menarik adalah masalah deskripsi tentang keluasan makna kata-kata bahasa Indonesia dan kata dalam bahasa Melayu Pattani. Fenomena persamaan dan perbedaan yang terjadi pada makna bahasa Indonesia dengan makna bahasa Melayu Pattani merupakan masalah yang menarik untuk diteliti karena setiap bahasa mempunyai kosakata atau kata-kata tertentu yang melambangkan identitas bahasa sendiri.

Namun demikian, setelah diamati ternyata kedua bahasa tersebut mempunyai unsur keluasan makna tersendiri karena perkembangan bahasa meliputi penambahan kata-kata baru yang menjadi ciri khas suatu tempat yang membedakannya dengan tempat lain. Perluasan makna juga terjadi dari sisi bunyi bahasa. Bunyi bahasa akan menjadi sangat beragam. Hal ini disebabkan oleh faktor geografis dan faktor ekonomis dari penggunaan bahasa itu. Selain itu, perluasan juga terjadi pada sisi makna. Beberapa makna menjadi meluas dan beberapa makna menjadi menyempit.

Untuk itu, dalam penelitian ini dilakukan pegkajian untuk menentukan keluasan makna kata dalam bahasa Indonesia dan dalam bahasa Melayu Pattani yang diujarkan oleh mahasiswa Thailand di Universitas Muhammadiyah Surakarta.

Penelitian ini difokuskan pada perbedaan makna kata-kata bahasa Indonesia dan bahasa Melayu Pattani yang digunakan oleh mahasiswa Thailand di Universitas Muhammadiyah Surakarta dengan tujuan menentukan keluasan makna kata dalam bahasa Indonesia dengan keluasan makna kata dalam bahasa Melayu Pattani yang diujarkan oleh mahasiswa Thailand di Universitas Muhammadiyah Surakarta.

Kajian teori yang digunakan dalam penelitian ini adalah kajian kontrastif semantik, khususnya mengenai perbedaan makna dan keluasan makna kata-kata dalam 
bahasa Indonesia dengan bahasa Melayu Pattani.

Menurut Suhardi (2013:28), semantik merupakan kajian lanjutan setelah melakukan kajian sintaksis. Kajian semantik adalah kajian yang berkaitan dengan makna. Dalam bidang ini, akan dijumpai makna leksikal, gramatikal asosiatif, dan sebagainya.

Keluasan makna dalam bahasa Indonesia dan bahasa Melayu Pattani adalah objek kajian dalam penelitian ini berdasarkan makna kata dalam bahasa Indonesia dan makna kata dalam bahasa Melayu Pattani dengan kerangka sebagai berikut.

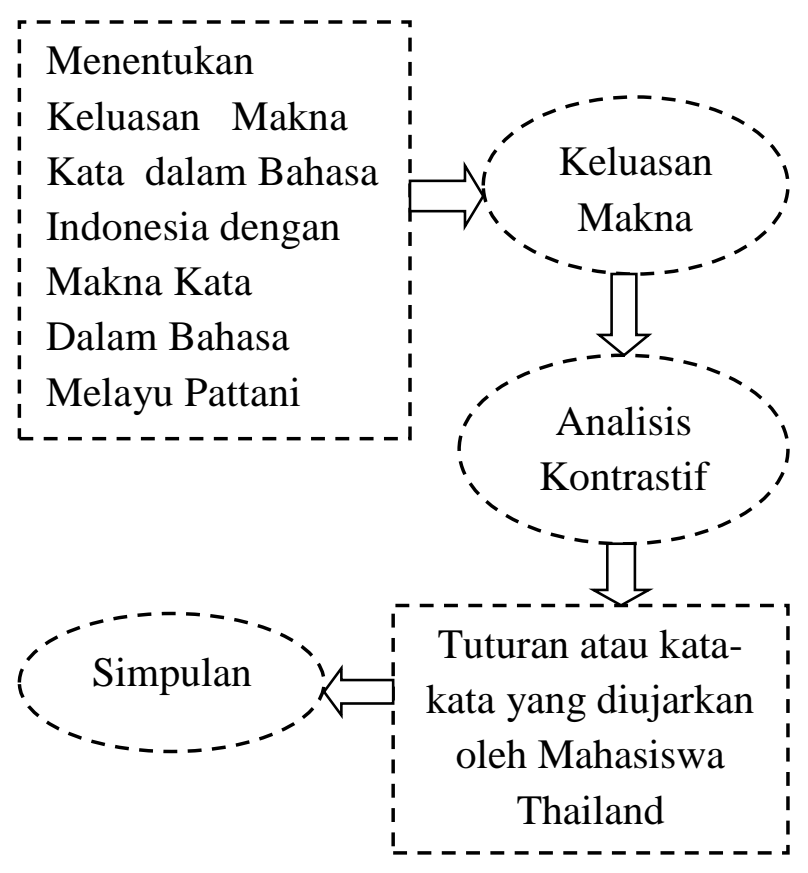

\section{Kerangka Teori}

Bahasa memiliki fungsi beragam. Setiap pakar bahasa memiliki rumusan fungsi bahasa yang berbeda sesuai dengan fokus-fokus penjelasnya. Sebelum disajikan bermacammacam fungsi bahasa oleh banyak pakar bahasa, ditegaskan terlebih dahulu bahwa fungsi bahasa yang paling utama adalah fungsi komunikasi dan interaksi. Bagi umat manusia, bahasa menjadi piranti utama dalam berkomunikasi dan berinteraksi dengan sesamanya (Rahardi, 2009:6).

Fungsi bahasa untuk berkomunikasi yaitu bahasa sebagai alat pergaulan dan berinteraksi dengan sesama manusia sehingga terbentuk sistem sosial/masyarakat. Bahasa adalah sistem lambang bunyi yang arbiter yang dipergunakan oleh masyarakat untuk berhubungan dan bekerjasama, berinteraksi dan mengidentifikasi diri (Kridalaksana, 1993:1).

Secara konseptual ilmiah, bahasa juga dapat dinyatakan sebagai salah hasil atau produk jiwa manusia (pikiran, perasaan, dan kehendak secara integratif) yang diekspresikan melalui hembusan udara, dari paru-paru yang berproses ke kerongkongan, ditopang oleh pita suara, keluar melalui rongga hidung dan rongga mulut sebagai alat ucap secara integratif pula. Produk dari proses tersebut adalah bahasa lisan. Sementara itu, jika dikehendaki untuk diwujudkan sebagai bahasa tulis, maka disajikan dengan lambang (simbol) yang disepakati oleh komunitas 
masyarakat (Ngalim, 2013:8).

Bahasa bukan satu-satunya alat komunikasi manusia. Karena itu, juga dikenal alat komunikasi isyarat, aneka simbol, kode, dan bunyi. Semua itu akan bermakna setelah diterjemahkan ke dalam bahasa manusia (Rohmadi dkk, 2010: v).

Bahasa mempunyai sistem bunyi dan makna. Keduanya saling terkait dan melengkapi. Suatu bunyi dapat ditimbulkan oleh berbagai hal, seperti bunyi deru mesin, pintu diketuk, tepuk tangan, dan bunyi yang diucapkan oleh manusia. Bunyi yang ditimbulkan oleh alat ucap manusia ada yang bermakna dan ada pula yang tidak bermakna. Bunyi yang bermakna disebut bahasa dan bunyi yang tidak bermakna termasuk bunyi yang ditimbulkan selain alat ucap manusia bukan bahasa. Bunyi yang ditimbulkan oleh alat ucap manusia yang tidak bermakna, misalnya bersin, batuk, mendehem, dan ucapan yang tidak memiliki makna seperti prindo, blankong, cisuat, serta masih sangat banyak (Nasucha,1997:1).

Berbicara tentang tuturan atau ujaran, di antara penutur dan mitra tutur, kedua-duanya ada interaksi linguistik untuk saling memahami makna atau maksud apa yang diujarkan oleh penutur dan untuk memudahkan memahami makna antara penutur dan mitra tutur. Dalam ilmu linguistik, ada bidang tertentu yang berkaitan dengan ilmu makna yaitu bidang semantik.

Menurut Chaer (1995), semantik adalah ilmu tentang makna atau tentang arti, yakni salah satu dari tiga tataran analisis bahasa (fonologi, gramatikal, dan semantik). Sejalan dengan Chaer, Pateda (1990) mengatakan bidang semantik adalah subdisiplin linguistik yang membicarakan makna.

Salah satu unsur bahasa Indonesia yang mengandung persamaan sekaligus perbedaan dengan unsur bahasa Melayu Pattani adalah makna. Makna dalam bahasa Indonesia dengan makna dalam bahasa Melayu Pattani terdapat perbedaan, kemiripan, keluasan, dan persamaannya.

Makna sebuah kata seringkali mengalami perluasan sehubungan dengan berkembangnya bidang aktivitas kehidupan manusia. Kebutuhan akan konsep baru seperti diketahui tidak selamanya harus dijawab dengan penciptaan kata baru, tetapi yang justru lebih sering ditempuh oleh pemakai bahasa adalah dengan memperluas komponen makna kata-kata yang sudah ada (Wijana dan Rohmadi, 2011: 92).

\section{Metode Penelitian}

Penelitian ini adalah deskriptif kualitatif. Subjek penelitian ini adalah tuturan atau kata-kata yang diujarkan oleh mahasiswa 
Thailand. Adapun objek penelitian ini adalah keluasan makna kata-kata dalam bahasa Indonesia dan tata kata dalam bahasa Melayu Pattani yang diujarkan oleh mahasiswa Thailand di Universitas Muhammadiyah Surakarta. Data penelitian diperoleh dari tuturan-tuturan dalam bentuk kalimat atau kata-kata yang diujarkan oleh mahasiswa Thailand.

Pengumpulan data dilakukan dengan teknik simak, teknik rekaman, dan teknik wawancara. Teknik simak bebas libat cakap dilakukan untuk menyimak apa yang diujarkan oleh mahasiswa Thailand dalam percakapan atau dialog. Setiap kata pada percakapan tersebut diperhatikan, kemudian kata-kata yang menggandung perbedaan makna dan keluasan makna dicatat. Teknik berikutnya yaitu teknik rekam. Teknik ini digunakan dengan pertimbangan bahwa data yang diteliti berupa data lisan. Setelah data direkam, peneliti mengidentifikasikan data yang menunjukkan perbedaan makna dan keluasan makna kata-kata bahasa Indonesia dan bahasa Melayu Pattani. Teknik wawancara yang digunakan adalah teknik pengumpulan data yang dilakukan secara langsung antara pewawancara dengan narasumber.

Setelah data terkumpul, tahapan berikutnya peneliti mengklasifikasikan data yang terdapat keluasan makna, kemudian menyeleksi data yang mengandung keluasan makna yang digabung oleh mahasiswa Thailand. Terakhir, peneliti menganalisis data keabsahan data dengan menggunakan teknik trianggulasi data. Selanjutnya, data dianalisis dengan metode padan dan metode analisis kontrastif. Prosedur penelitian dilakukan secara bertahap dengan cara peneliti menggarisbawahi kata yang mengandung keluasan makna, kemudian mengindentivikasi data berdasarkan wujud kategori, perbedaan, dan keluasan makna.

\section{Hasil dan Pembahasan}

\subsection{Keluasan Makna Kata-kata Bahasa Indonesia dan Bahasa Melayu Pattani}

Terdapat beberapa kata bahasa Indonesia yang maknanya lebih luas daripada bahasa Melayu Pattani, seperti; kata bisa, buruk, dan rapat. Terdapat perkataan yang tidak ada kesamaan makna, tetapi maknanya lebih luas dalam bahasa Indonesia. Kata tersebut dalam bahasa Melayu hanya mengandung makna satu saja. Oleh karena itu, dapat dikatakan bahwa makna dalam bahasa Indonesia lebih luas daripada makna dalam bahasa Melayu Pattani. 
Di samping itu, ditemukan kata-kata dalam bahasa Melayu Pattani yang maknaya lebih luas daripada bahasa Indonesia, seperti; kata angin, dan ingat. Terdapat perkataan yang mengandung makna lebih luas daripada bahasa Indonesia.

\subsection{Kata-kata Bahasa Indonesia yang Maknanya Lebih Luas}

\begin{tabular}{|c|c|c|c|}
\hline No & Kata & $\begin{array}{c}\text { Makna dalam Bahasa } \\
\text { Indonesia (BI) yang Lebih Luas }\end{array}$ & $\begin{array}{c}\text { Makna dalam Bahasa } \\
\text { Melayu } \\
\text { Pattani (MBP) }\end{array}$ \\
\hline 1 & bisa & $\begin{array}{l}\text { (1). Maтpu (kuasa melakukan sesuatu), semampu } \\
\text { yang dapat dikerjakan (2). Sedapatnya }\end{array}$ & (1). racun \\
\hline 2 & buruk & $\begin{array}{l}\text { (1). Rusak atau busuk karena sudah lama, (tetap } \\
\text { kelakuan dsb) (2). Jahat Tidak menyenangkan; tidak } \\
\text { cantik, tidak elok, jelek (tetap muka, rupa, dsb) (3). } \\
\text { Menjadi buruk hubungan kedua negara; menjadikan } \\
\text { (menyebabkan) buruk, usang, dsb (4). Berulang kali } \\
\text { mengatakan kejelek-jelekan; proses menjadi buruk }\end{array}$ & $\begin{array}{l}\text { (1). rusak, lama (2). } \\
\text { tidak berkelip-kelip lagi }\end{array}$ \\
\hline 3 & rapat & $\begin{array}{l}\text { (1). Hampir tidak berantara; dekat sekali (tidak } \\
\text { renggang), kerap (tetap tanaman, anyaman, dsb) (2). } \\
\text { Tertutup benar-benar hingga tidak bercelah, } \\
\text { berhampiran sekali; dekat benar (3). Pertemuan } \\
\text { (kumpulan) untuk membicarakan sesuatu; siding; } \\
\text { majelis; mendekati dengan perlahan-lahan dan } \\
\text { berhati-hati; tumbuhan menjalar, kulitnya dibuat } \\
\text { obat; kaya rapat }\end{array}$ & $\begin{array}{l}\text { (1). hampir tidak } \\
\text { berantara; dekat sekali } \\
\text { (tidak renggang, kerap } \\
\text { (tetap tanaman, } \\
\text { anyaman, dsb) (2). } \\
\text { tertutup benar-benar } \\
\text { hingga tidak bercelah, } \\
\text { berhampiran sekali; } \\
\text { dekat benar, Masuk } \\
\text { biar dekat, akrab }\end{array}$ \\
\hline
\end{tabular}

Analisis keluasan makna pertama kali didasarkan pada kata-kata bahasa Indonesia yang maknanya lebih luas. Dikatakan pertama kali, karena analisis berikutnya, yaitu berdasarkan pada kata-kata bahasa Melayu
Pattani yang maknanya lebih luas. Kata-kata bahasa Indonesia yang maknanya lebih luas yang diujarkan oleh mahasiswa Thailand, dapat dilihat pada contoh di bawah ini. 
(1) Ke- 2 (IV: 101) Kata bisa

Contoh: Kalimat dalam bahasa Indonesia (BI)

(2a) Ia membaca tetapi tidak bisa menulis.

(2b) Dia bisa mengatasi masalah yang berlaku atasnya.

(2c) Hukum Negara tidak bisa dilanggar malah kita harus ikuti dan mematuhi hukumnya

Contoh: Kalimat dalam bahasa Melayu Pattani (BMP)

(2d) Ular bisanya menyebabkan luka dan mematikan seseorang.

(2e) Siapa yang digigit Angjing bisanya sangat bahaya, karena banyak batteria di mulut anjing.

(2f) Binatang yang liar biasanya mempunyai bisa seperti ular, lebah, laba-laba dan sebagainya.

(2g) Bahaya bagi kalajengking adalah bisanya.

Contoh kalimat di atas jelas, perkataan bisa yang dipakai oleh mahasiswa Thailand adalah racun yang menyebabkan menjadi akibat atas manusia. Bagi pemakai bahasa Indonesia, kata tersebut biasa saja, karena mengandung makna 'mampu' atau 'kuasa' dalam sesuatu yang dilakukan.

Jadi, kata bisa dalam bahasa Indonesia maknanya lebih luas daripada dalam bahasa Melayu Pattani karena dalam bahasa Indonesia kata tersebut juga mengacu kepada makna 'mampu' atau 'kuasa', tetapi dalam bahasa Melayu Pattani, kata tersebut hanya mengacu kepada makna pada racun. Oleh karena itu, kata 'bisa' dalam bahasa Melayu Pattani lebih sempit maknanya daripada kata bisa dalam bahasa Indonesia.

(2) Ke-4 (IV: 104) Kata buruk

Untuk lebih mudah dan dapat gambaran antara pemakaian bahasa Indonesia dan pemakaian bahasa Melayu Pattani dan supaya tidak membingungkan kedua pemakaian bahasa tersebut, kita bisa menunjukkan pemakaian kata tersebut dalam kalimat bahasa Indonesia dan kalimat bahasa Melayu Pattani. Berikut ini adalah contoh kalimat pada kata tersebut. 
Contoh: Kalimat Dalam Bahasa Indonesia (BI).

(4a) Hubungan kedua Negara itu mulai buruk.

(4b) Pengkhianat itu selalu buruk nama bangsa dan negaranya.

(4c) Sudah sepuluh hari ia buruk muka dengan pamannya.

Contoh: Kalimat Dalam Bahasa Melayu Pattani (BMP).

(4d) Mobil bapak saya memiliki 10 tahun, kelihatannya warna sudah buruk tidak berkelip-kelip lagi.

(4e) Sudah lama tidak pergi ke toko buku, kemarin pergi ke sana ketemu buku yang suka dibaca, tetapi sampulnya buruk sekali.

(4f) Dia orang miskin, pakaian buruk tidak seperti orang lain.

(4g) Orang yang buruk akhlaknya adalah orang yang mekhiant dirinya sendiri.

Berdasarkan contoh kalimat di atas, dapat dibuktikan adanya kesamaan pemakaian kata tersebut dalam bahasa Indonesia dengan dan bahasa Melayu Pattani. Kata tersebut maknanya lebih luas dalam bahasa Indonesia daripada dalam bahasa Melayu Pattani, yakni 'tetap kelakuan dsb; 'jahat; tidak menyenangkan; menjadi buruk hubungan kedua negara'. Dalam Bahasa Melayu Pattani, kata tersebut maknanya lebih sempit, hanya mengacu makna pada 'barang' atau 'benda', seperti yang sudah dijelaskan pada beberapa contoh kalimat di atas.

Pada penjelasan di atas, bisa dinyatakan bahwa pemakaian bahasa dalam Melayu Pattani dan bahasa Indonesia mempunyai kesamaan dari segi keluasan makna. Di samping itu, pemakaian bahasa dalam Melayu
Pattani dan bahasa Indonesia mempunyai sedikit perbedaan.

(3) Ke-12 (IV: 123) Kata rapat

Menurut Kamus Besar Bahasa Indonesia (KBBI) (Edisi Ketiga, 2005: 931), kata rapat adalah; 'hampir tidak berantara; dekat sekali (tidak renggang)', 'kerap (tetap tanaman, anyaman, dsb)', 'tertutup benar-benar hingga tidak bercelah, berhampiran sekali; dekat benar'; 'pertemuan (kumpulan) untuk membicarakan sesuatu; sidang; majelis'; 'mendekati dengan perlahan-lahan dan berhatihati; menghampiri' 'meramahi; mengakrabi (untuk memperbaiki persahabatan)' 'tumbuhan menjalar, kulitnya dibuat obat; kaya rapat'.

Perkataan tersebut yang diujarkan oleh mahasiswa Thailand, yang mengandung 
kesamaan makna dengan bahasa Indonesia berhati-hati; menghampiri' 'meramahi; ialah 'hampir tidak berantara; dekat sekali (tidak renggang)', 'kerap (tetap tanaman, anyaman, dsb)', 'tertutup benar-benar hingga tidak bercelah, berhampiran sekali; dekat benar'. Tetapi dalam bahasa Melayu Pattani, kata rapat tidak mengacu makna pada kata pertemuan (kumpulan) untuk membicarakan sesuatu; sidang; majelis, dan kata meeting, hanya mengacu makna dekat, dekat sekali (tidak renggang) dan sebagainya.

Oleh karena itu, kata tersebut mengandung keluasan makna bagi pemakai bahasa bahasa Indonesia, yaitu; 'hampir tidak mengakrabi (untuk memperbaiki persahabatan)' 'tumbuhan menjalar, kulitnya dibuat obat; kaya rapat.

Bagi pemakai bahasa Melayu Pattani, kata tersebut maknanya lebih sempit karena hanya mengandung makna 'dekat', 'dekat sekali (tidak renggang)' dan sebagainya. Jadi, perkataan tersebut bagi pemakai bahasa Melayu Pattani maknanya lebih sempit daripada pemakai bahasa Indonesia. Buktinya jelas pada makna yang disebutkan di atas.

Supaya dapat gambaran antara pemakaian bahasa Indonesia dan pemakaian berantara; dekat sekali (tidak renggang)', bahasa Melayu Pattani, berikut ini ada 'kerap (tetap tanaman, anyaman, dsb)', beberapa contoh kalimat yang ditulis, agar 'tertutup benar-benar hingga tidak tidak membingungkan bagi dua pamakaian bercelah, berhampiran sekali; dekat benar'; bahasa tersebut. Contoh kalimat dalam bahasa 'pertemuan (kumpulan) untuk Indonesia dan bahasa Melayu Pattani.

membicarakan sesuatu; sidang; majelis';

'mendekati dengan perlahan-lahan dan

Contoh: Kalimat Dalam Bahasa Indonesia (BI).

(12a) Rumah-rumah di kota rapat sekali.

(12b) Padi jangan ditanam terlalu rapat.

(12c) Pada jam 2.00 siang nanti ada rapat bersama Rektor di kampus.

Contoh: Kalimat Dalam Bahasa Melayu Pattani (BMP).

(12d) Kemarin saya pergi kunjungan teman yang rapat (akrab) di Yala, ketika kita masih kuliah S1 di Universitas Fatoni.

(12e) Jiran tetangga sebelah kanan rumah saya dia rapat (akrab) dengaan keluarga saya. 
(12f) Zaman sekarang sulit untuk menemukan teman yang rapat (akrab), karena Teklologi memudahkan kita bisa ketemu dalam online, menyebabkan tidak salin kunjungan ke rumah seperti zaman lampau.

(12g) Sekarang sudah tidak punya lagi teman yang rapat, sebab dia sudah meninggal.

Beberapa contoh kalimat di atas dapat membuktikan bahwa kata rapat bagi pemakai bahasa Melayu Pattani dengan pemakai bahasa Indonesia ada yang sama dan ada yang berbeda maknanya. Makna yang sama adalah mengacu pada 'hampir tidak berantara; dekat sekali (tidak renggang)', 'kerap (tetap tanaman, anyaman, dsb)', 'tertutup benar-benar hingga tidak bercelah, berhampiran sekali; dekat benar'. Makna yang lebih sempit adalah makna dalam bahasa Melayu Pattani karena kata rapat hanya 'hampir tidak berantara; dekat sekali', tetapi tidak mengacu makna 'pertemuan'.
Data ini menunjukkan bahwa makna kata rapat dalam bahasa Indonesia lebih luas maknanya daripada makna kata rapat dalam bahasa Melayu Pattani.

Berdasarkan uraian di atas, dapat dinyatakan bahwa terdapat perkataan bahasa Indonesia yang maknanya lebih luas daripada bahasa Melayu Pattani. Di samping itu, dapat dikatakan bahwa ada beberapa perkataan dalam bahasa Indonesia yang mengandung kesamaan makna dengan bahasa Melayu Pattani.

\subsubsection{Kata-kata bahasa Melayu Pattani yang Maknanya Lebih Luas}

Dalam penelitian ini, ditemukan katakata bahasa Melayu Pattani yang maknanya lebih luas daripada dalam bahasa Indonesia.
Data tersebut dapat ditemukan pada kata-kata yang diujarkan oleh mahasiswa Thailand, seperti contoh di bawah ini. 


\begin{tabular}{|c|c|c|c|}
\hline No & Kata & $\begin{array}{l}\text { Makna dalam Bahasa } \\
\text { Indonesia (BI) }\end{array}$ & $\begin{array}{c}\text { Makna dalam Bahasa Melayu } \\
\text { Pattani (MBP) } \\
\text { yang Lebih Luas }\end{array}$ \\
\hline 1 & Angin & $\begin{array}{l}\text { (1). gerakan udara dari } \\
\text { daerah yang bertekanan } \\
\text { tinggi ke daerah yang } \\
\text { bertekanan rendah, hawa; } \\
\text { udara }\end{array}$ & $\begin{array}{l}\text { (1). gerakan udara dari daerah yang } \\
\text { bertekanan tinggi ke daerah yang } \\
\text { bertekanan rendah, hawa; udara, angin } \\
\text { (2). Takabur (3). sombong }\end{array}$ \\
\hline 2 & Ingat & $\begin{array}{l}\text { (1). berada dalam pikiran; } \\
\text { tidak lupa; timbul kembali } \\
\text { dalam pikiran; menaruh } \\
\text { perhatian; memikirkan } \\
\text { akan: ia sudah tidak ingat } \\
\text { lagi akan kewajibannya; } \\
\text { hati-hati; berwaswas (2). } \\
\text { mempertimbangkan } \\
\text { (memikirkan akan nasib } \\
\text { dsb); berniat; hendak }\end{array}$ & $\begin{array}{l}\text { (1). Berada dalam pikiran; tidak lupa; } \\
\text { timbul kembali dalam pikiran; menaruh } \\
\text { perhatian; (2). mempertimbangkan } \\
\text { (memikirkan akan nasib, dsb) (3). } \\
\text { Mencintai (4). rindu (5). ingat dari } \\
\text { hafalan }\end{array}$ \\
\hline
\end{tabular}

Ke-1 (IV: 125) Kata angin

Untuk mendapatkan gambaran tentang pemakaian kata tersebut dalam bahasa Indonesia dan bahasa Melayu Pattni, berikut ini diberikan contoh kalimat yang mengandung makna-makna tersebut, pada kalimat bahasa Indonesia dan kalimat dalam bahasa Melayu Pattani.

Contoh: Kalimat Dalam Bahasa Indonesia (BI).

(1a) Angin kencang merobohkan beberapa rumah penduduk.

(1b) Akhirnya perkara pembunuhan itu angin juga.

(1c) Kalau tak ada angin takkan pokok bergoyang.

Contoh: Kalimat Dalam Bahasa Melayu Pattani (BMP).

(1d) Pada 2 tahun yang lalu angin kencang (ribut topan) di daerah saya, merobohkan 20 jumlah rumah penduduk.

(1e) Setiap khabar harus jelaskan dahulu sebelum dipercayai, nanti kalau belum jelas khabar itu 
benar atau khabar angin.

(1f) Orang yang sudah kaya biasanya tidak peduli kepada orang yang miskin, sebab dia mempunyai sifat angin(sombong, takabur) pada orang miskin.

(1g) Islam tidak menggalakan umatnya mempunyai sifat yang melebihi atau angin (sombong, takabur) karena di sisi Allah SWT, memandang umatnya sama.

Menurut Kamus Besar Bahasa dengan pemakai bahasa Indonesia; kedua, Indonesia (KBBI) (Edisi Ketiga, 2005: 49), yang mengandung makna 'sombong', kata angin yakni; 'gerakan udara dari daerah 'membesarkan diri' dan 'takabur'. Kata yang bertekanan tinggi ke daerah yang bertekanan rendah'; 'hawa; udara'; 'gerakan udara yang untuk sementara waktu memperoleh sifat tertentu yang disebabkan oleh keadaan setempat'; 'angin yang datang dari arah laut ke darat dan terjadi pada siang hari'; 'kabar yang belum pasti (hanya kata orang)'; ' kabar yang belum tentu kebenarannya; desas-desas; gelagat yang menyatakan bahwa sesuatu akan terjadi'.

Kata tersebut yang diujarkan oleh mahasiswa Thailand dan pemakai bahasa Melayu Pattani mengandung dua makna dalam bahasa Melayu Pattani, pertama, makna yang mengacu pada 'gerakan udara dari daerah yang bertekanan tinggi ke daerah yang bertekanan rendah'; 'hawa; udara' makna tersebut adalan kesamaan

(1) Ke-4 (IV: 132) Kata ingat

Contoh: Kalimat Dalam Bahasa Indonesia (BI).

(4a) Pencuri itu dipukuli orang banyak hingga tidak ingat akan dirinya.

(4b) Keesokan harinya saya baru ingat siapa nama orang itu. 
(4c) Meskipun ayahnya telah berkali-kali hafal (ingat) Al-Quran setiap hari setelah sholat 5 waktu.

Contoh: Kalimat Dalam Bahasa Melayu Pattani (BMP).

(4d) Ahmad sudah jatuh cinta kepada seorang wanita, setiap sore dia menelphone ke pacarnya dan bilang aku ingat kepada mu.

(4e) Bunyi gemuruh itu ingat ketika masih kecil, sedang main air hujan di halaman rumah.

(4f) Ku hanya satu agar berjumpa dengan dia, aku masih ingat kepada dia tidak bisa lupa wajahnya.

(4g) Jangan lupa, ingatlah banyak membuat amalan yang disukai oleh Allah SWT, supaya tidak menyesalkan ketika kembali kepada Allah.

Berdasarkan uraian di atas, dapat dijelaskan bahwa pemakaian kata tersebut dalam bahasa Melayu Pattani, selain mempunyai kesamaan makna dengan bahasa Indonesia merut Kamus Besar Bahasa Indonesia, juga mengandung keluasan makna. Makna yang menunjukkan lebih luas dalam bahasa Melayu Pattani maknanya adalah makna kata 'rindu', 'cintai' dan 'kasih sayang'.

Kalimat di atas menunjukkan beberapa kata yang mengandung keluasan makna, antara pemakaian kata dalam bahasa Indonesia dengan pemakaian kata dalam bahasa Melayu Pattani. Jadi, kata ingat dalam bahasa Melayu Pattani, maknanya lebih luas daripada makna ingat dalam tuturan bahasa Indonesia.

Di samping itu, kata-kata dalam bahasa
Melayu Pattani yang maknanya lebih luas dicontohi dua kata yang mengandung keluasan makna, setiap kata muncul makna yang sama dengan pemakai bahasa Indonesia. Tetapi setiap perkataan tersebut tidak semua sama maknanya, hanya separuh kata yang sama dan pada makna yang lain tidak sama. Hal itu menyebabkan makna dua kata tersebut dalam bahasa Melayu Pattani lebih luas daripada dalam bahasa Indonesia berdasarkan makna yang bersumber dari Kamus Besar Bahasa Indonesia dan kata-kata yang bersumber dari mahasiswa, penelitian, dan pemakai bahasa Melayu Pattani.

Hasil analisis yang menentukan keluasan makna dalam penelitian ini ada dua. Pertama, kata-kata yang ditemukan adalah 
kata-kata yang maknaya lebih luasa dalam bahasa Indonesia. Kata tersebut mengandung beberapa makna yang sama dengan bahasa Melayu Pattani, sebagian kata maknanya sama, tetapi tidak semua kata itu sama maknanya karena beberapa kata dalam bahasa Indonesia mengadung makna, sedangkan dalam bahasa Melayu Pattani tidak mengandung makna tersebut. Kedua, katakata yang ditemukan adalah kata-kata yang maknaya lebih luas dalam bahasa Melayu Pattani. Kata tersebut mengandung beberapa komponem makna yang sama dengan bahasa Indonesia, tetapi tidak semua kata terhadap bahasa Melayu Pattani itu komponen sama maknanya, menyebabkan bahasa Melayu Pattani maknanya lebih luas daripada dalam bahasa Indonesia.

Hasil temuan tersebut terkait dengan perbedaan makna, kesamaan makna, dan keluasan makna dalam bahasa Indonesia dan keluasan makna dalam bahasa Melayu Pattani. Hal ini dapat dilihat pada gambar berikut.

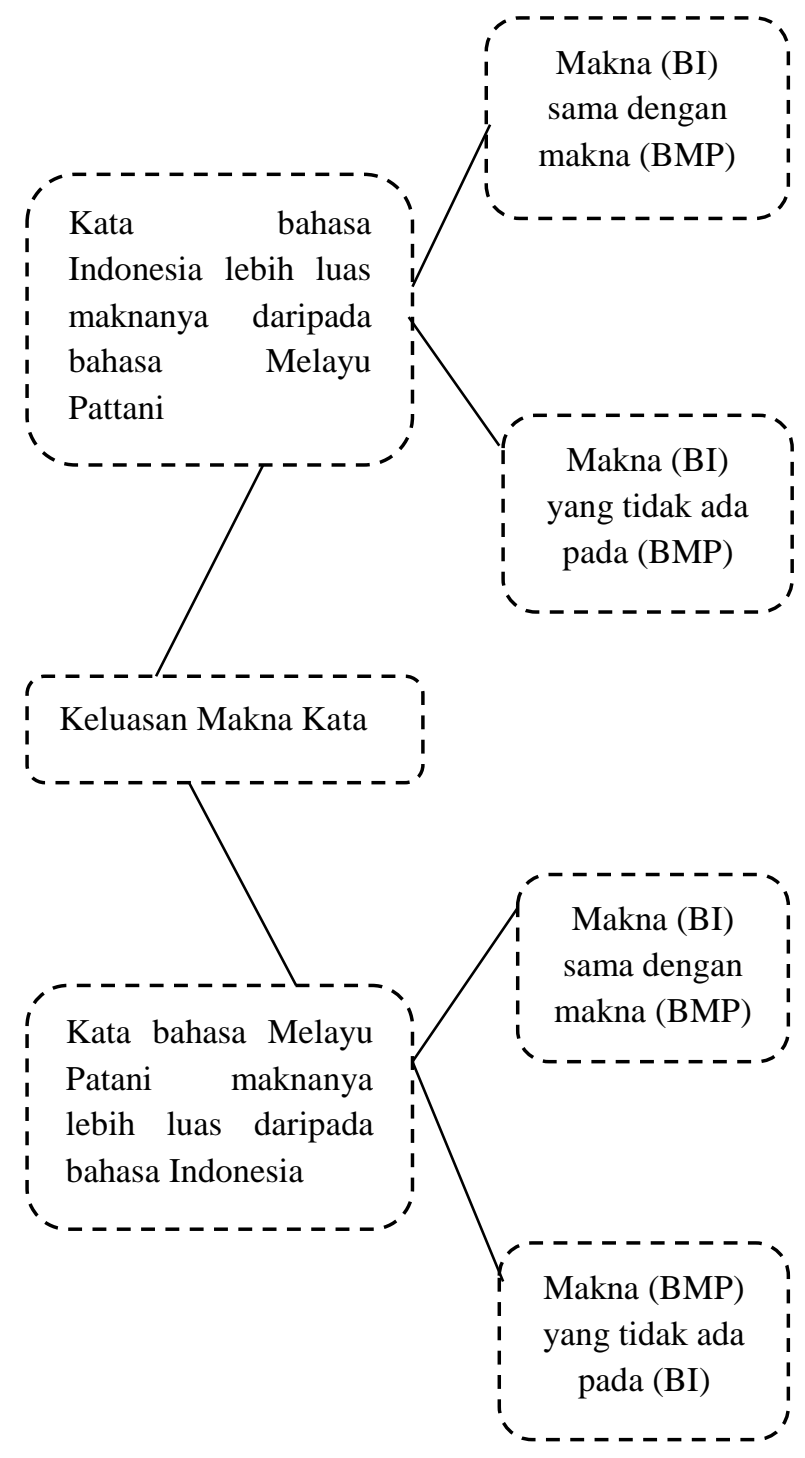


Dari hasil analisis dan temuan di atas, terdapat perbedaan dan persamaan penelitian terdahulu dengan penelitian ini. Penelitian terdahulu yang dimaksud adalah penelitian Apriliana, dkk (2015). Hasil penelitian ini memiliki persamaan dengan penelitian tersebut. Persamaannya adalah sama-sama mendeskripsikan bagaimana variasi keluasan makna.

Di samping persamaan, penelitian ini berbeda hasilnya dengan penelitian tersebut. Perbedaannya adalah penelitian ini memfokuskan diri pada keluasan makna dalam bahasa Melayu Pattani yang diujarkan oleh Mahasiswa Thaland, bentuk kata-kata yang sama tetapi maknanya lebih luas daripada bahasa Melayu Pattani. Sedangkan penelitian tersebut mendeskripsikan bagaimana variasi keluasan makna interpersonal pada teks Laskar Pelangi bahasa Indonesia, Inggris, dan Melayu.

Hasil penelitian ini juga memiliki persamaan dengan penelitian Christine dan Sufriati (2014). Persamaan adalah kedua penelitian ini menganalisis dan mendeskripsikan variasi keluasan makna. Di samping persamaan, penelitian ini berbeda hasilnya dengan penelitian tersebut. Perbedaannya adalah adalah penelitian ini menentukan kata-kata yang diujarkan oleh mahasiswa Thailand pada perkataan bahasa Indonesia yang maknanya lebih luas daripada bahasa Melayu Pattani, sedangkan penelitian tersebut berfokus pada fitur-fitur temuan yang menonjol dan dianggap penting untuk disajikan dari wujud variasi KMI berupa penambahan dan pengurangan elemen makna interpersonal pada T2, tingkat variasi keluasan makna pada keseluruhan klausa T2, faktor-faktor penyebab KMI, serta pengaruh variasi KMI tersebut terhadap kesepadanan makna $\mathrm{T} 2$.

Hasil penelitian ini juga memiliki persamaan dengan penelitian Jalaluddin, dkk (2012). Persamaannya adalah kedua penelitian ini mendeskripsikan keluasan makna. Adapun hasil analisis yang terdapat pada penelitian tersebut yakni makna 'alim' telah meluas kepada makna-makna lain dan berbeda dengan kamus (Kamus Dewan Edisi ke-4, 2007). Di samping persamaan, penelitian ini berbeda hasilnya dengan penelitian tersebut. Perbedaannya adalah penelitian ini tidak fokus pada makna kata 'alim', tetapi difokuskan pada kata angin, buku, darat, ingat, 
jaman, kasar, kereta, maja, mani, meninggal, sampul, sayur, suka, dan surat, kata yang maknanya lebih luas daripada makna dalam bahasa Indonesia.

Hasil penelitian ini juga memiliki persamaan dengan penelitian Bebetho, dkk (2013). Persamaannya adalah kedua penelitian ini bertujuan mendeskripsikan dan menjelaskan bentuk kata dan makna. Hasil yang terdapat dalam penlitian tersebut adalah istilah-istilah yang terdapat dalam setiap tahapan mengalami perluasan makna, penyempitan makna, dan tidak mengalami perubahan makna. Di samping persamaan, penelitian ini berbeda hasilnya dengan penelitian tersebut. Perbedaannya adalah peluasan makna pada penelitian ini berbentuk kata-kata yang diujarkan oleh mahasiswa Thailand, bukan berbentuk istilah-istlah dalam bahasa Melayu Pattani ataupun bahasa Indonesia.

Hasil penelitian ini juga memiliki persamaan dengan penelitian Devi (2013). Persamaan adalah kedua penelitian ini bertujuan mendeskripsikan variasi keluasan makna dan sama-sama menganalisis dua novel dengan fokus pada satuan-satuan klausa yang mewujudkan satuan-satuan makna tekstual. Di samping persamaan, penelitian ini berbeda hasilnya dengan penelitian tersebut. Tujuan penelitian ini tidak fokus kepada satuan-satuan klausa yang mewujudkan satuan-satuan makna tekstual, tetapi fokus pada keluasan makna yang kata atau kalimat dalam bahasa Indonesia yang sama sebutan dan tulisan dengan bahasa Melayu Pattani, sekaligus menentukan keluasan makna dalam bahasa Indonesia dan bahasa Melayu Pattani.

\section{Penelitian Alindah} memiliki persamaan dengan penelitian ini yaitu sama-sama memfokukan diri pada keluasan makna. Di samping persamaan, penelitian ini berbeda hasilnya dengan penelitian tersebut. Perbedaannya adalah penelitian ini tidak memfokuskan diri pada keluasan makna interpersonal dalam teks berbahasa Arab, Inggris dan Indonesia, tetapi memfokuskan diri pada keluasan makna, yakni berupa sumber dari katakata yang diujarkan oleh mahasiswa Thailand, sedangkan penelitian tersebut bersumber data teks.

\section{Penutup}

Berdasarkan hasil analisis dan pembahasan di atas, dihasilkan dua simpulan, yaitu pertama, terdapat 
beberapa kata bahasa Indonesia yang maknaya lebih luas daripada bahasa melayu Pattani, seperti kata bisa, buruk, dan rapat. Terdapat perkataan yang tidak ada kesamaan makna, tetapi maknanya lebih luas daripada bahasa Melayu Pattani, kata tersebut dalam bahasa Melayu Pattani hanya mengandung makna satu saja. Kedua, terdapat kata-kata dalam bahasa Melayu Pattani yang maknaya lebih luas daripada bahasa Indonesia, seperti kata angin dan ingat. Terdapat perkataan yang mengandung makna yang lebih luas daripada bahasa Indonesia. Kata dalam bahasa Indonesia tersebut hanya mengandung makna sebagian, tidak mengandung semua komponen makna. Hal itu menyebabkan makna kata tersebut dalam bahasa Melayu Pattani lebih luas daripada dalam bahasa Indonesia.

\section{Daftar Pustaka}

Alindah, Lutfiyah. (2012). "Variasi Keluasan Makna Interpersonal dalam Teks Translasional Multibahasa 'Imro'at 'inda Nuqthat al-Shifr' Berbahasa Arab, Inggris dan Indonesia". Tesis. Yogyakarta: Universitas Negeri Yogyakarta.
Apriliana, Hapsari; Asruddin, Barori Tou. (2015). "Variasi Keluasan Makna Interpersonal Teks Laskar Pelangi Berbahasa Indonesia, Inggris, Dan Melayu”. Jurnal LingTera. Vol 2, No 1. Mei 2015. hlm, 12--26 ISSN: 2406-9213.

Bebetho, dkk. (2013). "Istilah-Istilah Yang Digunakan Pada Acara Ritual Petik Pari Oleh Masyarakat Jawa Di Desa Sumberpucung Kabupaten Malang (Kajian Etnolinguistik)". Jurnal Ilmu Budaya dan Media. Vol 1, No 1. November 2013. hlm 64--78. eISSN: 2338-9923.

Chaer, Abdul. (1995). Pengantar Semantik Bahasa Indonesia. Jakarta : PT. Rineka Cipta.

Christine, Dian Permata Sari \& Sufriati, Tanjung. (2014). "Variasi Keluasan Makna Interpersonal Teks Translasional Lintas Bahasa Novel Botchan Berbahasa Jepang Dan Indonesia”. Jurnal LingTera. Vol 1, No. 1, Mei 2014.

Devi, Rosmawati. (2013). "Variasi Keluasan Makna Tekstual Dalam Teks Dwibahasa Five On The Treasure dan Lima Sekawan di Pulau Harta" Adabiyyat, Juranal Bahasa dan Sastra. Vol 12 No. 2.

Jalaluddin; Sarudin; dan Ahmad. (2012). "Peluasan Makna Alim: Analisis Semantik Kognitif”. Journal of Language Studies. Vol. 12. No 2, May 2012 hlm, 457-473. ISSN: 1675-8021. 
Kamus Besar Bahasa Indonesia. (2005).

Edisi Ketiga. Departemen

Pendidikan Nasional: Balai

Pustaka.

Kridalaksana, Harimurti. (1993). Kamus

Linguistik. Jakarta: Gramedia Pustaka Utama.

Nasucha,Yakub.(1997). Morfologi Bahasa Indonesia. Surakarta: Universitas Muhammadiyah Surakarta.

Ngalim, Abdul. (2013). Sosiolinguistik. Surakarta: PSID FKIP UMS.

Pateda, Mansoer. (1990). Linguisti Sebuah Pengantar. Bandung: Angkasa.

Rahardi, Kunjana. (2009). Bahasa Indonesia Untuk Perguruan Tinggi. Jakarta: Erlangga.

Rohmadi, Muhammad dkk. (2010). Morfologi Telaah Morfologi dan Kata. Surakarta: Yuma Pustaka.

Suhardi. (2013). Pengantar Linguistik Umum. Jogjakarta: Ar-Ruzz Media.

Wardhaugh, Ronald. (1972). Introduction to Sociolinguistics. McGrawn-Hill: New York.

Wijana, I Dewa Putu \& Rohmadi, Muhammad. (2011). Semantik Teori dan Analisis. Surakarta: Yuma Pustaka. 